\title{
Radiographic adenoid evaluation: proposal of an objective parameter*
}

\author{
Avaliação radiográfica da tonsila faringea: proposição de um método de medição objetivo
}

\section{Murilo Fernando Neuppmann Feres ${ }^{1}$, Juliana Sato Hermann ${ }^{2}$, Ana Carolina Sallum ${ }^{3}$, Shirley Shizue Nagata Pignatari $^{4}$}

Feres MFN, Hermann JS, Sallum AC, Pignatari SSN. Radiographic adenoid evaluation: proposal of an objective parameter. Radiol Bras. 2014 Mar/ Abr;47(2):79-83.

Abstract Objective: The objective of the present study was to evaluate current radiographic parameters designed to investigate adenoid hypertrophy and nasopharyngeal obstruction, and to present an alternative radiographic assessment method.

Materials and Methods: In order to do so, children (4 to14 years old) who presented with nasal obstruction or oral breathing complaints were submitted to cavum radiographic examination. One hundred and twenty records were evaluated according to quantitative radiographic parameters, and data were correlated with a gold-standard videonasopharyngoscopic study, in relation to the percentage of choanal obstruction. Subsequently, a regression analysis was performed in order to create an original model so the percentage of the choanal obstruction could be predicted.

Results: The quantitative parameters demonstrated moderate, if not weak correlation with the real percentage of choanal obstruction. The regression model $(110.119 * \mathrm{~A} / \mathrm{N})$ demonstrated a satisfactory ability to "predict" the actual percentage of choanal obstruction. Conclusion: Since current adenoid quantitative radiographic parameters present limitations, the model presented by the present study might be considered as an alternative assessment method in cases where videonasopharyngoscopic evaluation is unavailable.

Keywords: Adenoids; Mouth breathing; Radiography; Diagnosis.

Res u mo Objetivo: 0 objetivo deste estudo foi avaliar parâmetros radiográficos atuais destinados à verificação da adenoide e obstrução nasofaríngea e apresentar um método de avaliação alternativo.

Materiais e Métodos: Crianças (4 a 14 anos) que apresentavam queixas de obstrução nasal e/ou respiração oral foram submetidas ao exame radiográfico de cavum faríngeo. Cento e vinte registros foram avaliados por parâmetros radiográficos quantitativos, e estes dados foram correlacionados ao exame de videonasofaringoscopia, aqui considerado como padrão ouro, em relação à porcentagem de obstrução coanal. Posteriormente, uma análise de regressão foi realizada com os mesmos parâmetros quantitativos, de modo que um modelo original fosse criado com o objetivo de predição do percentual de obstrução coanal.

Resultados: Os parâmetros quantitativos atuais demonstraram correlações moderadas, quando não fracas, ao percentual de obstrução. O modelo de regressão desenvolvido $(110.119 * \mathrm{~A} / \mathrm{N})$ demonstrou capacidade satisfatória de "prever" o real percentual de obstrução adenóidea.

Conclusão: Uma vez que os parâmetros radiográficos atuais apresentam limitações, o modelo original aqui apresentado deve ser considerado como um método de avaliação adenóidea alternativo, a ser utilizado quando a videonasofaringoscopia estiver indisponível.

Unitermos: Tonsila faríngea; Respiração bucal; Radiografia; Diagnóstico.

\section{INTRODUCTION}

Adenoid radiographic evaluation has been extensively debated over the years ${ }^{(1-17)}$. Yet, opinions regarding lateral cavum $\mathrm{x}$-ray usefulness are still varied. This uncertainty might

* Study developed in the Department of Otorhinolaryngology and Head \& Neck Surgery at Escola Paulista de Medicina - Universidade Federal de São Paulo (EPMUnifesp), São Paulo, SP, Brazil.

1. Professor, Division of Preventive and Interceptive Orthodontics, Universidade São Francisco, Bragança Paulista, SP, Brazil.

2. Master, Fellow PhD degree of Pediatric Otorhinolaryngology, Department of Otorhinolaryngology and Head \& Nerck Surgery, Escola Paulista de Medicina Universidade Federal de São Paulo (EPM-Unifesp), São Paulo, SP, Brazil.

3. Master, Private Practice in São Paulo, SP, Brazil.

4. PhD, Professor, Division of Pediatric Otorhinolaryngology and Head \& Neck Surgery, Escola Paulista de Medicina - Universidade Federal de São Paulo (EPMUnifesp), São Paulo, SP, Brazil. be related to the absence of comprehensive studies which simultaneously investigate a considerable number of radiographic parameters ${ }^{(18,19)}$. Sample discrepancies, as well as diverse, if not questionable, methods are other reasons for this subject to remain under scientific doubt ${ }^{(18,19)}$.

Up to the present moment, most of the studies addressed at investigating cavum radiography utility have demonstrated several methodological limitations, when comparing radiographic parameters with questionable reference exams $s^{(1,2,8)}$, and analyzing an inadequate "disease" spectrum ${ }^{(3,5,7,11,12-}$ ${ }^{14,16)}$. Even though clinical examination is mandatory in cases

Mailing Address: Dr. Murilo Fernando Neuppmann Feres. Rua Afonso Celso, 982 ap. 12, Vila Mariana. São Paulo, SP, Brazil, 04119-060. E-mail: mn-feres@uol.com.br.

Received July 2, 2013. Accepted after revision October 17, 2013. 
of nasal obstruction, and videonasopharyngoscopy (VNP) has proved to be absolutely effective to identify their etiology ${ }^{(20)}$, the usefulness of lateral cavum radiography still deserves investigation. Considering that this is the most requested complementary otolaryngological exam on in the Brazilian public health system ${ }^{(21)}$, it is justifiable to submit such topic to a comprehensive analysis.

Therefore, the aim of this study is to assess adenoid hypertrophy and nasopharyngeal obstruction by correlating multiple radiographic measurements with gold-standard VNP. Additionally, this study intends to present an alternative and potentially useful assessment method.

\section{MATERIALS AND METHODS}

The present research is a cross-sectional methodological study, and was approved by the institutional Ethics Review Board (protocol 0181/08).

In order to form the study sample, 170 children from a public pediatric otolaryngology referral center, in the age range between 4 and 14 years, were invited to participate, but 43 refused to be part of the research. Thus, 127 children of both genders agreed to be part of the study, after detailed description of the procedures, and proper explanation of the study objective, risks, discomforts, and benefits. A term of free and informed consent was signed by all the participants.

In order to meet inclusion criteria, patients should report complaints about nasal obstruction or oral breathing suspected to be caused by adenoid hypertrophy. Children with congenital syndromes or head and neck malformations were excluded. Subjects with acute infection of the respiratory tract or with history of previous adenoidectomy were also excluded.

Initially, all the children underwent cavum radiography (Instrumentarium Ortopantomographic OP100; General Electric Healthcare, Tuusula, Finland), which was performed by a single radiology specialist. Focus-film distance was 140 $\mathrm{cm}$, and $\mathrm{x}$-ray exposure settings were $70 \mathrm{kV}, 12 \mathrm{~mA}$, for 0.40 to 0.64 second. During the procedure, patients were standing, and instructed to breathe exclusively through the nose, keeping their lips gently sealed. The central $\mathrm{x}$-ray beam was directed towards the nasopharyngeal anatomic area. Images showing elevation of the soft palate or significant rotation of the head were discarded.

Lateral radiographs (Kodak; Rochester, USA) were number-coded and hand-traced by one of the researchers, who were blind to the subjects' identification as well as their clinical conditions. Several radiographic measurements were made by the mentioned observer (Table 1, Figure 1). Tracings were performed on acetate films laid over a negatoscope (3Munitek; Campinas, Brazil). Linear measurements were determined with a digital caliper (Starrett, 799A-8/200; Itu, Brazil).

On the same day, the selected sample was submitted to VNP performed by experienced otolaryngologists. The examination was performed with a flexible fiberoptic nasopharyngoscope (Olympus, ENFP4, $3.4 \mathrm{~mm}$; Melville, USA), with 250 watts halogen light. All exams were performed after topical anesthesia application (lidocaine $2 \%$ ) in both nostrils. At any sign of discomfort, the procedure was interrupted.

All exams were recorded and then edited to keep the identification of the patient preserved. The edited VNP clips were number-coded, and then handed to another observer, an experienced otolaryngologist, and distinct from the ones involved in the subjects' enrollment, VNP performance, recording, and editing. The mentioned observer was also blinded to the radiographic examination results, as well as to the subjects' respiratory symptoms and complaints.

In order to evaluate the VNP clips, the observer used an assessment method designed to quantify the degree of obstruction caused by the adenoid tissue, i.e. "measured choanal obstruction" (MCO), which has already proved to be satisfactorily reproducible ${ }^{(26)}$. The observer was instructed to choose the frame that would provide the best view of the adenoid in relation to the choana, obtained from the most distal portion of the inferior turbinate. At these frames, the patient should be inspiring exclusively through the nose, with no evidence of the soft palate elevation. The selected frame was then converted into a digital file (JPEG format), and the $\mathrm{MCO}$ was finally calculated by Image $\mathrm{J}^{(27)}$, an image

Table 1-Radiographic parameters and respective reference studies.

\begin{tabular}{|c|c|}
\hline Reference studies & Radiographic parameters \\
\hline Jóhannesson (22) & $\begin{array}{l}\text { Nasopharyngeal tonsil }(\mathrm{NpT})(\mathrm{mm}) \text { : greatest width of the soft tissue outlined anterior to the site of the pharyngeal tubercle, perpendicular } \\
\text { to the bony roof of the nasopharynx (Figure } 1 \mathrm{~A})\end{array}$ \\
\hline Fujioka et al. ${ }^{(23)}$ & $\begin{array}{l}\text { Adenoid/ nasopharyngeal ratio }(\mathrm{A} / \mathrm{N}) \text { : ratio between adenoid and nasoparyngeal space. Adenoid }(\mathrm{A}) \text { : greatest distance between a line drawn } \\
\text { along the straight part of the inferior margin of the basiocciput and the point of maximal convexity of the anterior outline of adenoid. } \\
\text { Nasopharyngeal space }(\mathrm{N}) \text { : distance between the posterior and superior edge of the hard palate and posteroinferior margin of the } \\
\text { sphenobasioccipital syncondrosis (Figure } 1 \mathrm{~B} \text { ) }\end{array}$ \\
\hline Crepeau et al..$^{(\mathbf{1})}$ & $\begin{array}{l}\text { Antroadenoid diameter }(\mathrm{AA})(\mathrm{mm}) \text { : shortest distance between the anterior outline of adenoid and the posterior wall of the maxillary antrum, } \\
\text { which lies in the same plane as the posterior choanae (Figure } 1 \mathrm{C} \text { ) }\end{array}$ \\
\hline Maw et al. ${ }^{(24)}$ & Palatal airway $(P A)(\mathrm{mm})$ : shortest distance between the anterior outline of adenoid and the soft palate (Figure 1C) \\
\hline Cohen et al. ${ }^{(25)}$ & $\begin{array}{l}\text { Air column }(\mathrm{AC})(\mathrm{mm}) \text { : distance between the superior outline of soft palate (at } 10 \mathrm{~mm} \text { from the posterior edge of the hard palate) and the } \\
\text { anterior outline of adenoid (Figure } 1 \mathrm{D}) \\
\text { Air column/ soft palate ratio }(A C / S P) \text { : ratio between } A C \text { (see above) and } S P \text {, which represents the thickness of the soft palate (at } 10 \mathrm{~mm} \\
\text { from the posterior edge of the hard palate) (Figure } 1 \mathrm{D})\end{array}$ \\
\hline Mlynarek et al. ${ }^{(12)}$ & $\begin{array}{l}\text { Airway occlusion }(A O)(\%) \text { : ratio between } N p T \text { (see above) and nasopharynx }(N p) \text {, which represents the distance between pharyngeal } \\
\text { tubercle and the superior outline of the soft palate (Figure } 1 \mathrm{~A})\end{array}$ \\
\hline
\end{tabular}



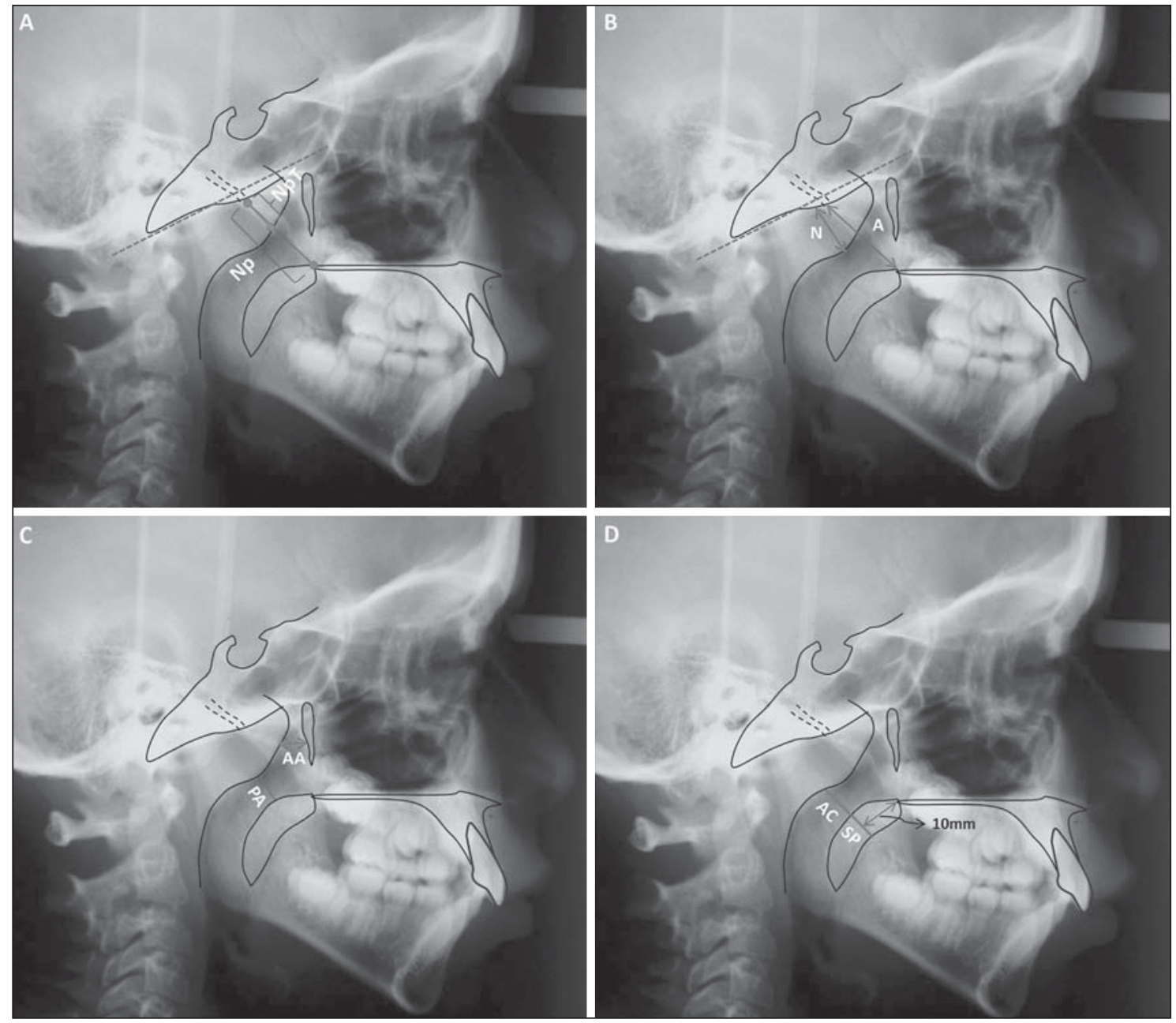

Figure 1. Quantitative radiographic parameters illustration. A: NpT, nasopharyngeal tonsil; Np, nasopharynx. B: A, adenoid; N, nasopharyngeal space. C: AA, antroadenoid; PA, palatal airway. D: AC, air column; SP, soft palate.

processing software, as the percentage of the choanal area occupied by the adenoid tissue (Figure 2). If images from both nostrils were available, the average between the right and left sides evaluations was calculated in order to minimize occasional variations, as recommended by Feres et al. ${ }^{(26)}$.

\section{Data analysis}

Initially, the sample was described according to demographic data, respiratory complaints and research variables. Subsequently, Pearson correlation analyses $(r)$ were undertaken between radiographic variables $(\mathrm{N} p \mathrm{~T}, \mathrm{~A} / \mathrm{N}, \mathrm{AA}, \mathrm{PA}$, $A C, A C / S P$, and $A O)$, and MCO. Correlation was considered "irrelevant" $(0<\mathrm{r} \leq 0.25)$, "weak" $(0.25<\mathrm{r} \leq 0.50)$, "moderate" $(0.50<\mathrm{r} \leq 0.75)$ or "strong" $(0.75<\mathrm{r} \leq 1.00)^{(28)}$.

With the intent of creating an alternative radiographic evaluation parameter, a linear regression analysis was performed, according to which all of the quantitative radiographic parameters were considered as independent variables, and the MCO was regarded as the dependent variable. The evaluation of consecutive models was accomplished, among other criteria, by the determination of the adjusted coefficient $\left(R^{2}\right)$, which varies from 0.00 to 1.00 and indicates how

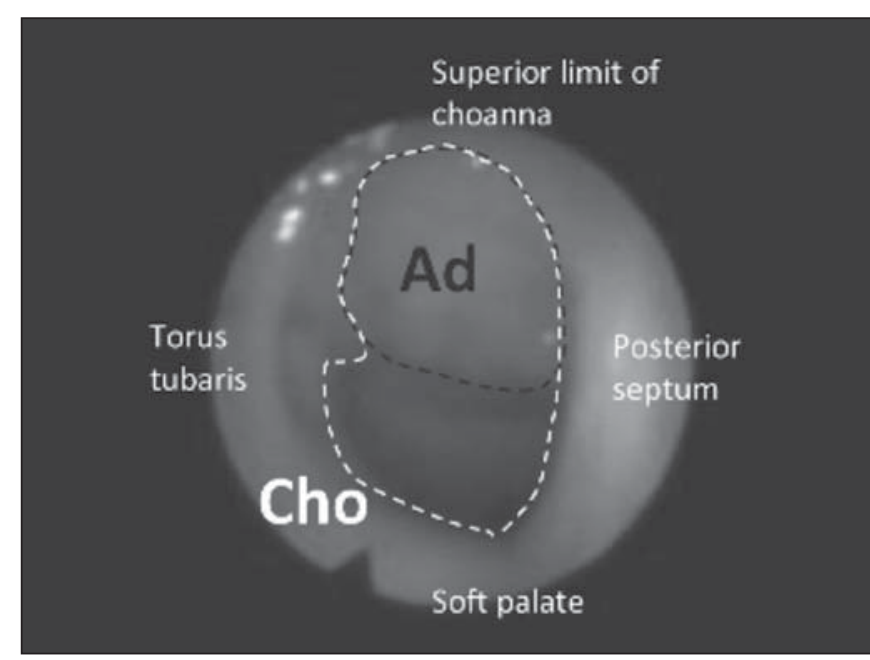

Figure 2. Measured choanal obstruction. Ad, adenoid area; Cho, choanal area.

precisely MCO might be "predicted" from quantitative radiographic parameters variation. Additionally, the mean differences between the actual value of the MCO and the percentage of choanal obstruction obtained from each model resolution were also calculated. 
The level of significance for the statistical analyses was $5 \%(\alpha \leq 0.05)$. All calculations and analyses were performed with the aid of the SPSS 13.0 software.

\section{RESULTS}

Seven out of the initial 127 patients were excluded due to imperfect cavum radiograph or VNP quality. Bilateral VNP examination was not performed on $32 / 120$ subjects (26.66\%), who had MCO values derived from a single nostril evaluation.

The final sample was composed of 120 subjects (female: 59 / 49.16\%; male: $61 / 50.83 \%$ ), mean age of 9.45 years (standard deviation: 2.45; minimum: 4.08; maximum: 14.33). Nasal breathing was reported by few subjects $(7 / 5.83 \%)$, while exclusive oral breathing was reported by 56 subjects $(46.66 \%)$. However, most of the subjects reported mixed (oral/ nasal) breathing ( $57 / 47.50 \%)$. The majority of the sample (99/82.50\%) was composed of nasal obstruction complainers; most of whom described it as being bilateral (63/99), and irregular (69/99). According to reports, 107 (89.16\%) children experienced frequent snoring, and 61 children (50.83\%) experienced interruption in breathing during sleep.

Table 2 presents the MCO description, as well as the descriptive analysis of the radiographic parameters. According to VNP evaluation, the subjects presented approximately 2/3 of adenoid obstruction.

According to the correlation analysis, all of the quantitative parameters presented significant correlation with MCO, ranging from "weak" (AC/SP) to "moderate" $(\mathrm{N} p \mathrm{~T}$, $A / \mathrm{N}, A A, P A, A C$, and $A O$ ) (Table 3).

Linear regression analysis was performed in order to generate mathematical models, with the inclusion of different

Table 2 - Descriptive analysis of the MCO, quantitative, and categorical radiographic parameters.

\begin{tabular}{lccc}
\hline & Variables & Mean $\pm \mathrm{SD}^{*}$ & Min-Max $^{\dagger}$ \\
\hline $\begin{array}{l}\text { VNP examination } \\
\text { (gold-standard) }\end{array}$ & MCO (\%) & $67.49 \pm 18.37$ & $9.16-100.0$ \\
Radiographic & NpT (mm) & $15.14 \pm 3.66$ & $8.39-24.98$ \\
parameters & A/N & $0.62 \pm 0.12$ & $0.33-0.88$ \\
& AA (mm) & $7.03 \pm 2.84$ & $0.00-19.14$ \\
& PA (mm) & $7.50 \pm 3.37$ & $1.15-18.62$ \\
& AC (mm) & $8.77 \pm 3.42$ & $2.50-25.38$ \\
& AC/SP & $1.21 \pm 0.58$ & $0.34-3.55$ \\
& AO (\%) & $61.24 \pm 13.81$ & $25.78-94.82$ \\
\hline
\end{tabular}

* Standard deviation; ${ }^{\dagger}$ Minimum to maximum.

Table 3-Correlation ( $r$ ) of quantitative radiographic parameters in relation to MCO.

\begin{tabular}{lcc}
\hline Variables & $r$ & Pearson $(p$-value $)$ \\
\hline NpT $(\mathrm{mm})$ & 0.558 & $<0.001$ \\
A/N & 0.720 & $<0.001$ \\
AA $(\mathrm{mm})$ & -0.620 & $<0.001$ \\
PA $(\mathrm{mm})$ & -0.730 & $<0.001$ \\
AC $(\mathrm{mm})$ & -0.650 & $<0.001$ \\
AC/SP & -0.476 & $<0.001$ \\
AO $(\%)$ & 0.674 & $<0.001$ \\
\hline
\end{tabular}

radiographic quantitative parameters diversely combined with each other. Only two models (model \#1: 110.119*A/N; and model \#2: 117,367*A/N $\left.-0,557^{*} \mathrm{PA}\right)$ presented significant performances $\left(R^{2}=0.970\right.$, and $R^{2}=0.971$, respectively). Model \#1 calculation "predicted" MCO value with a mean error of $9.51 \%$ (standard deviation: $7.50 \%$; minimum: $0.14 \%$; maximum: $40.20 \%$ ). Model \#2 presented mean difference of $9.61 \%$ (standard deviation: $7.20 \%$; minimum: $0.12 \%$; maximum: $33.08 \%$ ) between its resolution and MCO value.

\section{DISCUSSION}

Although already investigated by many studies ${ }^{(1-17)}$, the cavum radiography usefulness in the evaluation of adenoid hypertrophy and nasopharyngeal obstruction is not yet precisely determined. Two major factors might have contributed to the persistence of this scientific debate, i.e. the methodological diversity and the presence of several flaws in most of the study designs and methods ${ }^{(18,19)}$.

The present study, supported by relevant literature ${ }^{(12,20,29)}$, has, however, elected the VNP as the gold-standard, and the inclusion criteria have necessarily created a characteristic sample which represents the population, i.e. subjects suspected to have adenoid hypertrophy, from whom complementary studies such as cavum radiography, are usually requested. Moreover, it has investigated a significant number of radiographic parameters ${ }^{(1,2,4,12,14,22-25)}$, and has satisfied other essential ${ }^{(30)}$ methodological requirements, such as blinding of the observers in relation to the subjects' symptoms and complaints, as well as to the other examination results; a comprehensive description of the exams; and the moment in time they were performed. Consequently, such features have assured proper scientific reliability to the evidence provided by the present study.

The majority of the present quantitative parameters have demonstrated only moderate correlation with MCO (TF, $A / N, A A, P A, C A, O V A)$. Such results are similar to those reported in the literature ${ }^{(3,5,7,12,17)}$ and validate scientific efforts to provide an alternative assessment tool capable of estimating the percentage of adenoid obstruction (MCO) as accurately as possible. For this purpose, a linear regression analysis was performed in order to create models. Despite many attempts and combinations, only two models presented remarkable performances (model \#1 and model \#2), and the model \# 1 (110.119*A/N) was found to be slightly superior, demonstrating to estimate the real value of MCO with reasonable reliability. By calculating it, it was possible to "predict" the MCO value with minor inaccuracy (approximately $10 \%)$. Additionally, model $\# 1\left(110.119^{*} \mathrm{~A} / \mathrm{N}\right)$ is more practical than model \#2 $\left(117,367^{*} \mathrm{~A} / \mathrm{N}-0,557^{*} \mathrm{PA}\right)$, since it exclusively relies on a single variable $(A / N)$ to be calculated. The authors of the present study believe that such an instrument may become an important alternative adenoid evaluation tool, whenever the VNP is unavailable.

Inferences apart, further studies are still required to confirm the efficiency of this method $\left(110.119^{*} \mathrm{~A} / \mathrm{N}\right)$ for its pur- 
pose, i.e. for prediction of choanal obstruction percentage. Furthermore, longitudinal studies should also enroll larger samples with diverse mean ages to verify if the presently suggested parameter can also distinguish which patient might benefit from specific therapeutic approaches, such as adenoidectomy. And finally, the authors still encourage future studies intended to adapt model \#1 $\left(110.119^{*} \mathrm{~A} / \mathrm{N}\right)$ as a digital assessment tool. The provision of a reliable, useful computerassisted evaluation method might enable standardization and universalization of radiographic adenoid evaluation.

\section{CONCLUSION}

Based on the analyses provided by the present study, the authors conclude that current quantitative adenoid radiographic parameters presented significant limitations, such as moderate correlation with videonasopharingoscopic examination. On the other hand, Model \#1 $\left(110.119^{*} \mathrm{~A} / \mathrm{N}\right)$ demonstrated to be a safe alternative assessment tool to estimate severity of adenoid obstruction, in cases where VNP is not available.

\section{Acknowledgements}

The present study was financially supported by Fundação de Amparo à Pesquisa do Estado de São Paulo (Fapesp) (São Paulo Research Foundation), process No. 08/53538-0.

\section{REFERENCES}

1. Crepeau J, Patriquin HB, Poliquin JF, et al. Radiographic evaluation of the symptom-producing adenoid. Otolaryngol Head Neck Surg. 1982;90:548-54.

2. Elwany $\mathrm{S}$. The adenoidal-nasopharyngeal ratio (AN ratio). Its validity in selecting children for adenoidectomy. J Laryngol Otol. 1987;101:569-73.

3. Wormald PJ, Prescott CA. Adenoids: comparison of radiological assessment methods with clinical and endoscopic findings. J Laryngol Otol. 1992;106:342-4.

4. Wang DY, Bernheim N, Kaufman L, et al. Assessment of adenoid size in children by fibreoptic examination. Clin Otolaryngol Allied Sci. 1997;22:172-7.

5. Chami FAI. Endoscopic and roentgenographic approach in patients with adenoids hyperplasia. Rev Bras Med Otorrinolaringol. 1998; 5:118-24.

6. Paradise JL, Bernard BS, Colborn DK, et al. Assessment of adenoidal obstruction in children: clinical signs versus roentgenographic findings. Pediatrics. 1998;101:979-86.

7. Cho JH, Lee DH, Lee NS, et al. Size assessment of adenoid and nasopharyngeal airway by acoustic rhinometry in children. J Laryngol Otol. 1990;113:899-905.

8. Kemaloglu YK, Goksu N, Inal E, et al. Radiographic evaluation of children with nasopharyngeal obstruction due to the adenoid. Ann Otol Rhinol Laryngol. 1999;108:67-72.

9. Monteiro ECM, Pilon RR, Dall'Oglio GP. Study of enlarged adenoids: endoscopy versus radiography of the nasophrynx. Braz J Otorhinolaryngol. 2000;66:9-12.

10. Souza BB, Hennemann GV, Anselmo-Lima WT. Importance of nasal fiberoptic examination in the presence of a normal X-ray of the cavum. Int J Pediatr Otorhinolaryngol. 2000;55:29-32.

11. Oliveira RC, Anselmo-Lima WT, Souza BB. The importance of nasal fiberoptic examination to diagnose adenoid hyperplasia in children with normal paranasal sinuses X-ray. Braz J Otorhinolaryngol. 2001; 67:499-505.

12. Mlynarek A, Tewfik MA, Hagr A, et al. Lateral neck radiography versus direct video rhinoscopy in assessing adenoid size. J Otolaryngol. 2004;33:360-5.

13. Lourenço EA, Lopes KC, Pontes Jr A, et al. Comparison between radiological and nasopharyngolaryngoscopic assessment of adenoid tissue volume in mouth breathing children. Braz J Otorhinolaryngol. $2005 ; 71: 23-7$.

14. Kurien M, Lepcha A, Mathew J, et al. X-rays in the evaluation of adenoid hypertrophy: it's role in the endoscopic era. Indian J Otolaryngol Head Neck Surg. 2005;57:45-7.

15. Kindermann CA, Roithmann R, Lubianca Neto JF. Sensitivity and specificity of nasal flexible fiberoptic endoscopy in the diagnosis of adenoid hypertrophy in children. Int J Pediatr Otorhinolaryngol. 2008;72:63-7.

16. Ysunza A, Pamplona MC, Ortega JM, et al. Video fluoroscopy for evaluating adenoid hypertrophy in children. Int J Pediatr Otorhinolaryngol. 2008;72:1 159-65.

17. Caylakli F, Hizal E, Yilmaz I, et al. Correlation between adenoidnasopharynx ratio and endoscopic examination of adenoid hypertrophy: a blind, prospective clinical study. Int J Pediatr Otorhinolaryngol. 2009;73:1532-5.

18. Major MP, Flores-Mir C, Major PW. Assessment of lateral cephalometric diagnosis of adenoid hypertrophy and posterior upper airway obstruction: a systematic review. Am J Orthod Dentofacial Orthop. 2006;130:700-8.

19. Feres MF, Hermann JS, Cappellette M Jr, et al. Lateral X-ray view of the skull for the diagnosis of adenoid hypertrophy: a systematic review. Int J Pediatr Otorhinolaryngol. 2011;75:1-11.

20. Bitar MA, Birjawi G, Youssef M, et al. How frequent is adenoid obstruction? Impact on the diagnostic approach. Pediatr Int. 2009;51:478-83.

21. T-Ping C, Weckx LL. ENT care of children and adolescents in the Brazilian public health system in three different municipalities. Braz J Otorhinolaryngol. 2008;74:571-8.

22. Jóhannesson S. Roentgenologic investigation of the nasopharyngeal tonsil in children of different ages. Acta Radiol Diagn (Stockh). 1968;7:299-304.

23. Fujioka M, Young LW, Girdany BR. Radiographic evaluation of adenoidal size in children: adenoidal-nasopharyngeal ratio. AJR Am J Roentgenol. 1979;133:401-4.

24. Maw AR, Jeans WD, Fernando DC. Interobserver variability in the clinical and radiological assessment of adenoid size, and the correlation with adenoid volume. Clin Otolaryngol Allied Sci. 1981;6: 317-22.

25. Cohen D, Konak S. The evaluation of radiographs of the nasopharynx. Clin Otolaryngol Allied Sci. 1985;10:73-8.

26. Feres MFN, Hermann JS, Sallum AC, et al. Endoscopic evaluation of adenoids: reproducibility analysis of current methods. Clin Exp Otorhinolaryngol. 2013;6:36-40.

27. ImageJ. [webpage]. Imaging processing analysis. US National Institutes of Health; 1997. [cited 2014 Mar 12]. Available from: http:// imagej.nih.gov/ij/.

28. Vieira S. Introdução à bioestatística. $4^{\mathrm{a}}$ ed. Rio de Janeiro: Elsevier; 2008.

29. Kubba H, Bingham BJ. Endoscopy in the assessment of children with nasal obstruction. J Laryngol Otol. 2001;115:380-4.

30. Cook C, Cleland J, Huijbregts P. Creation and critique of studies of diagnostic accuracy: use of the STARD and QUADAS methodological quality assessment tools. J Man Manip Ther. 2007;15:93102. 